\title{
TRANSLATION AS A TEACHING TOOL TO BRIDGE L1 AND L2 FOR ADULT LEARNERS AT ELEMENTARY LEVELS ${ }^{1}$
}

\author{
Natanael F. França Rocha \\ Universidade Federal de Santa Catarina \\ natanffr@gmail.com
}

\begin{abstract}
This paper aims to investigate the extent to which translation is useful in foreign language teaching for adult learners at elementary levels. Although the effectiveness of translation has been questioned, this study presents reasons why a language teacher should resort to this tool. The research drew on data collected from written translation exercises of elementary learners at a language center in the city of Londrina, Parana, Brazil, in 2009. The exercises were analyzed by examining the occurrence and disappearance of errors lesson by lesson. The results demonstrated that the act of translating fosters learning.
\end{abstract}

Keywords: translation, foreign language teaching, adult learners, elementary levels, errors.

Resumo: Este artigo propõe investigar quão útil a tradução pode se mostrar no ensino de línguas estrangeiras para alunos adultos em nível inicial. Embora ainda muito se questione sobre a efetividade da tradução, este estudo apresenta razões pelas quais um professor de idiomas pode recorrer a essa ferramenta. A pesquisa se baseou em dados coletados a partir de exercícios de tradução escritos de aprendizes adultos em uma escola de idiomas na cidade de Londrina, PR, Brasil, em 2009. Os exercícios foram analisados com base na ocorrência e não-ocorrência de erros lição por lição. Os resultados demonstraram que o ato de traduzir contribui para o aprendizado do aluno.

Palavras-chave: tradução, ensino de língua estrangeira, aprendizes adultos, nível inicial, erros. 


\section{Introduction}

Although the use of translation in Foreign Language Teaching (FLT) has been either banned, avoided, or at least "viewed with suspicion" (WIDDOWSON, 1979, p. 101) among language teachers, linguists, and researchers, this study aims to show that the "act of translating", mentioned by Machida (2008, p. 140), can be beneficial for adult beginners as a transitional stage between mother tongue and a foreign language.

At the outset I would like to make a few explanatory notes on the terminology used in this study.

I opted to use the terms L1 and L2 with a wider connotation. Here, L1 refers to first language/mother tongue/source language (SL); and L2 refers to a second language/foreign language/target language (TL). All these terms will appear throughout the text as having virtually the same meaning. In addition, the term oral translation refers to oral exercises done in the classroom (e.g. students orally translate into L2 a sentence given by the teacher in L1); the term written translation refers to written exercises done both in class and at home (e.g. sentences in L1 to be translated into L2 or vice-versa). As for the use of $L 1$ in class I mean the verbal communication of the teacher in the classroom (e.g. giving instructions, checking comprehension, explaining a word/expression, etc.).

Based on quantitative analysis, the primary aim of this study was to investigate to what extent translation can be useful in FLT for adult beginners. Secondary aims were addressed to improve the status of translation in FLT and to raise awareness of how powerful it can be if well applied.

In the seven years that I have worked as a language teacher, I have had good experiences with translation, despite all the prejudice against it that I have found. I strongly defend the proposal that translation plays an important role at the beginning of the teaching-learning process. Thus, I consider it of great relevance for the field that an investigation is directed towards the helpfulness of translation in FLT. 
To conclude this section, I quote from Stoddart (2000), who points out that "students do, and always will, translate into their L1, no matter how often we [teachers] exhort them not to" and that "perhaps we should stop working against this tendency and turn it to our advantage" (p. 6).

\section{Translation: Dangerous? Harmful? Negative?}

The Grammar-Translation Method has already run its course; its reestablishment in FLT as a core method is definitely out of the question. In fact, the proposal of reconsidering translation in FLT may be regarded more as an additional skill than a major method. As Soares (2006, p. 7) puts it,

Translation will be harmful in FLT whenever it is used as a [core] learning method, when the teacher assumes that, by translating [as to check comprehension], students will learn, and when interferences that translation might cause are not eradicated.

Heltai (1989, p. 292) argues that "translation is a dangerous exercise, since it enhances interference from the mother tongue". Ridd $(2004$, p. 7$)$, in a partial agreement, makes the point that at early levels the degree of interference does increase, but it tends to subsequently decrease. Furthermore, Mallikamas (1997, p. 29) states that in recent times the idea that translation and mother tongue bring negative transference to the target language is no longer strongly supported. Shiyab and Abdullateef (2001, p. 7) explain that

[...] translation can be like medicine, which, when administered in the right dose and way, has a curative effect, and otherwise, when used injudiciously, it can also prove harmful. 
According to these authors, by using translation teachers do not invite interference, but provide means "to overcome it and to create, using medical parlance again, anti-interference immunity and resistance" (SHIYAB; ABDULLATEEF, 2001, p. 7). Stoddart (2000, p. 6) stresses that "translation does have a place in the classroom and that its implementation can be beneficial for learners". As an English teacher, he warns that "as international integration grows, translation will become more and more necessary for non-native speakers of English" (STODDART, 2000, p. 6) and adds that it would be unfair of him to withhold this valuable technique from his students.

From another point of view, Machida (2008, p. 154), based on the findings of his own study, 2 states that "translation as a main teaching methodology is feasible, and appears potentially an effective method for teaching L2". He argues that such methodology focuses on where the learners demonstrate "insufficient understanding by failing to translate appropriately". His research sought to investigate the extent to which the class could incorporate translation activities, the potential strengths of the method and the students' perceptions.

Because translation has prevailed in FLT over the centuries, it would be senseless to frown upon it. In fact, teachers should look at it differently and take advantage of this very powerful tool which they have within easy reach. However, it is worth keeping in mind that, as stated by Shiyab and Abdullateef (2001), translation can be like medicine: it has either a curative or a harmful effect.

\section{Translation for adult beginners}

Although many authors take up a position mainly in favor of translation at advanced levels of learning (e.g. ATKINSON, 1987; DUFF, 1989; POPOVIC, 2001; SHIYAB; ABDULLATEEF, 2001; PHILIPPS, 2003; WELKER, 2004; ROMANELLI, 2006), its use as a supporting tool or as a bridge between L1 and L2 can be significantly beneficial at elementary levels. Beginners may 
encounter a great barrier when they first enter a classroom, more than ever if it is a monolingual class in L2. The first contact with L2 might frustrate the learner who does not have any previous knowledge of the language studied. In such cases, Romanelli (2006, p. 3 ) stresses that translation helps the learner to overcome difficulties that he or she may initially have due to poor knowledge of L2.

It is important to point out that adult learning is different from childhood and adolescent learning. Translation is more appropriate for adult learners because it consists of a "cognitively demanding process" (POPOVIC, 2001, p. 2). Moreover, Heltai (1989, p. 289) states that "cognitively oriented learners value translation because it helps their linguistic knowledge" and adds that adults especially benefit from "a mixed approach that contains elements of the communicative approach and more traditional methods, and not from an approach that is communicative only" (HELTAI, 1989, p. 290).

According to Costa (1988, p. 288), the more dissimilar the structures of L1 and L2 are, the more frequent the need for translation will be at elementary levels of learning. The author also explains the benefits of oral and written translation separately. He states that oral translation is a direct means of explaining the meaning of certain words, as well as identifying student difficulties which might pass unnoticed. As for written translation, it enables the teacher to check the learner's writing skill, vocabulary comprehension, syntax, idioms and the use of different registers. In addition, Popovic (2001, p. 3) suggests that some "simple L1-L2 translation activities, especially those involving awareness raising, can also be carried out at the initial stages of learning".

\section{Translation: a bridge that must be crossed}

Translation can be a useful tool when the teacher knows how to properly apply it. If poorly applied, it may actually be detrimental to Foreign Language Teaching. 
Considering that a language is acquired only once (i.e. the mother tongue) and that any other languages will be learned, one can say that translation (at least mental) is essential to the learning process. The learner makes associations with the mother tongue and such information will be retrieved at any time he or she switches to L2. Petrocchi (2006, p. 1) notes that "when students translate, they unconsciously follow three steps: analysis, transfer, and restructuring" and adds that "a mental process takes place in their minds on an unconscious level, every time they speak the other language". Shiyab and Abdullateef (2001, p. 4) state that

[...] the learner makes use of the prior knowledge that exists within him and that there is a process of mental translation going on throughout the process of language learning.

Kremer and Koppe (2007, p. 2), referring to Deller and Rinvolucri (2002), observe that "it is through the mother tongue that the other languages are born in the learner's mind" and that translation skills are used from the very beginning of the learning process of any language, including the mother tongue. Therefore, to teach a foreign language without using the student's first language, according to Deller and Rinvolucri (2002), is like weaning a baby on her/his first day of life.

As mentioned above, foreign language learning involves mental connections between L1 and L2 made by the learner in order to store and retrieve information. Mainly at the initial stages of learning, such connections will be more evident, since the student is building a bridge between both languages. This bridge, that must be crossed, is the transition between mother tongue and target language. Kremer and Koppe (2007, p. 446) state that "students have to build this bridge between L2 and L1, using translation as a transformation from one language to another" and observe that when students are conscious of similarities and differences between the mother tongue and L2, the learning process will become easier. 
The advantages of using translation to teach a foreign language are certainly far more significant than the drawbacks. I can mention seven reasons why teachers should resort to translation in order to foster conscious language learning. By using translation, teachers are able to introduce new vocabulary, explain grammar, contrast culture, promote motivation, help with memorization, check students' comprehension, and help them deal with pitfalls. These should be more than enough to prove how useful translation can be, if well applied, in the classroom. Below I explore three of the reasons indicated.

\subsection{Motivation}

For students having their first contact with L2, translation could motivate and prevent them from quitting the lessons. Atkinson (1987, p. 242) emphasizes that "translation techniques form a part of the preferred learning strategies of most learners in most places". Although there are many studies and new approaches that defend total immersion in the target language since the first class, an immediate contact with a new language might be frustrating (e.g. ATKINSON, 1993, p. 13; PHILIPPS, 2003, p. 27), especially for adults. It is important to remember that sitting in a classroom completely unable to follow a teacher's discourse can be both traumatic and discouraging. That is when translation can make a difference; teachers can resort to translation in an attempt to make students feel more comfortable about following the lessons, facilitating the learning process and the transition from L1 to L2.

\subsection{Memorization}

Translation may also help learners to memorize words and expressions. When performing a translation, students get in touch with the essence of the word, its etymology, and possible equivalents for it in L1. They can make associations and comparisons 
with the mother tongue so as to facilitate memorization. Petrocchi (2006, p. 2) points out that "paying attention to etymology is another strategy that helps [learners] memorize and understand the real meaning of that word in its context and co-text". She also suggests that "a word-for-word back-translation enables the student to highlight the relationship between the two languages" (PETROCCHI, 2006, p. 3).

Some idiomatic expressions become easy to memorize in transliteration, due to their ridiculousness in L1. For instance, the English expression to pull one's leg sounds bizarre when put literally into Portuguese, and learners may associate it with the idea of someone teasing their friend by pulling their leg while they're trying to walk and thus memorize it with ease. To hear something straight from the horse's mouth, when taken literally (at least in Portuguese), is also completely baffling. The mental image of talking to a horse (the source), however, due to its shock value, may help form an association with hearing something from an unbiased, direct source. In such cases, translation can be a helpful tool since we recall funny and weird things more easily. As Gabrielatos (1998, p. 23) puts it:

The literal translation in English serves to demonstrate how different cultures express the same factual information in distinctly different ways in terms of wording, explicitness, amount and focus on different aspects.

Pegenaute (1996, p. 117) also makes the point that literal translation of some L2 expressions can facilitate understanding and memorization. Moreover, Kremer and Koppe (2007, p. 446) state, referring to Lewis (2002), that "it is inevitable that learners use L1 as a resource and make certain right or wrong suppositions, based on their experience with the mother tongue". Then, again, literal translation can also lead to gaffes and confusion if used normatively to communicate in L2. The teacher must be vigilant in 
informing students that translation cannot always be literal and that one-to-one correspondence may actually be odd (the examples given above illustrate that clearly).

\subsection{Pitfalls}

Another contribution of translation to the teaching and learning of a foreign language is that it can serve as a check against the pitfalls that learners may encounter, for instance, false cognates or idiomatic expressions which are apparently coherent in L1 (e.g. to kick the bucket - meaning to die in English - is also an idiomatic expression in Portuguese - literally chutar o balde -, but it means to give up or to lose one's temper). Comparing words and considering whether they are cognates is also a sort of translation. In order to classify a word as a false cognate, it must be correlated with another word either in L1 or L2. Atkinson (1987, p. 244) points out that the translation of a paragraph containing several known false cognates "obligates students to focus on the problem of a set of apparent but misleading similarities between the two languages". Moreover, Catford (1965, p. 49) asserts that "the SL and TL items rarely have 'the same meaning' in the linguistic sense; but they can function in the same situation". In some cases, the real meaning of certain words will be understood only within a given context. The learner may resort to a monolingual dictionary and make use of paraphrase, namely intralingual translation, in order to confirm his or her assumptions. Nevertheless, an explanation in L2 may not be so clarifying to the student, even after listening to many examples of use from the teacher. In such cases, translation can be a significant tool. In a bilingual dictionary, the learner will probably be able to find an equivalent term in the mother tongue for the confusing word. Thompson $(1987$, p. 286) points out that, for beginners, "the bilingual dictionary can do all the useful things that the monolingual dictionary can do; and it can do several of the things in a more efficient and more motivating way". 


\section{Methodology}

This paper drew on data collected from the homework of four learners at a private language center in the city of Londrina, Parana, Brazil. This group was selected because the students were adult beginners taking basic classes of English. Two of the students worked for multinational companies that required them to learn English fluently. Out of the four learners, two had never studied English before. One had been in contact only with technical English at work, and the other one had already studied English for about one year with the same teaching method.

The data analysis was carried out on the basis of the recurrence and disappearance of errors. I collected eighteen pieces of homework in addition to three Reviews3 from each of the students. I identified their mistakes and also the absence of mistakes in the "Written Practice" section. My aim was to do a survey of students' performance on this specific translation exercise and then relate success or failure to the usefulness of translation. By means of this quantitative analysis, I was able to track their learning development in terms of error disappearance and proper use of the language.

The "Written Practice" section consists of eight short sentences in Portuguese which are expected to be translated into English with the vocabulary presented in the student textbook. These sentences did not have a common context. However, all of them are meaningful and could be used in daily life conversations.

According to the teaching methodology of the language center, for every lesson completed students are expected to complete one homework assignment for the following class. Reviews were done only during class; students were given twenty minutes to complete the written section and were instructed not to look at their textbooks. Both Reviews and homework consisted of the following four exercise types: Complete/Substitute/Listen/Translate. The latter, called "Written Practice", was chosen for analysis (see sample in Appendix I). 
In order to facilitate the analysis, an inventory with eight categories of the most common errors in the students' homework was constructed (see Appendix II).

The most common types of errors were: I. Omission/misuse of preposition (e.g. "I like of bread"/"I go the movies"); II. Infinitive without to (e.g. "I want go to the movies"); III. Adjective after noun (e.g. "I need a house new"); IV. Wrong word (e.g. "I play with my sons" instead of "children"); V. Omission of auxiliary do (e.g. "You like to play soccer?"); VI. Omission of personal pronouns (e.g. "Prefer to go now"); VII. Excessive word(s) (e.g. "I want to work every day" Expected: "I work every day"); VIII. Other omissions (e.g. "I to go downtown"/“I want only cup of coffee").

Finally, I applied a questionnaire with seven questions to check students' impressions about translation. The questionnaire didn't directly relate to the analysis, but it was used to confirm whether translation is, in fact, regarded as tedious by most students.

The results of the questionnaire and the quantitative analysis are presented below.

\section{Results}

In the questionnaire, the respondents were asked which of the four activities in the homework sheet (Complete/Substitute/Listen/ Translate) they considered to be the most difficult. The unanimous answer was Listen. All of the students regarded the translation exercise as helpful and easy to do. None regarded it as dull. As for oral translation in class, half of the group considered it to be difficult. On a $1-5$ scale, $75 \%$ of the students rated their enjoyment of the written translation exercise as 5 , while the remaining student gave it a 3. None of the students wished to replace the translation exercise with something else.

The figure below shows the students' performance on the "Written Practice" exercise included in the Reviews. 


\section{WRITTEN PRACTICE - STUDENTS' PERFORMANCE}

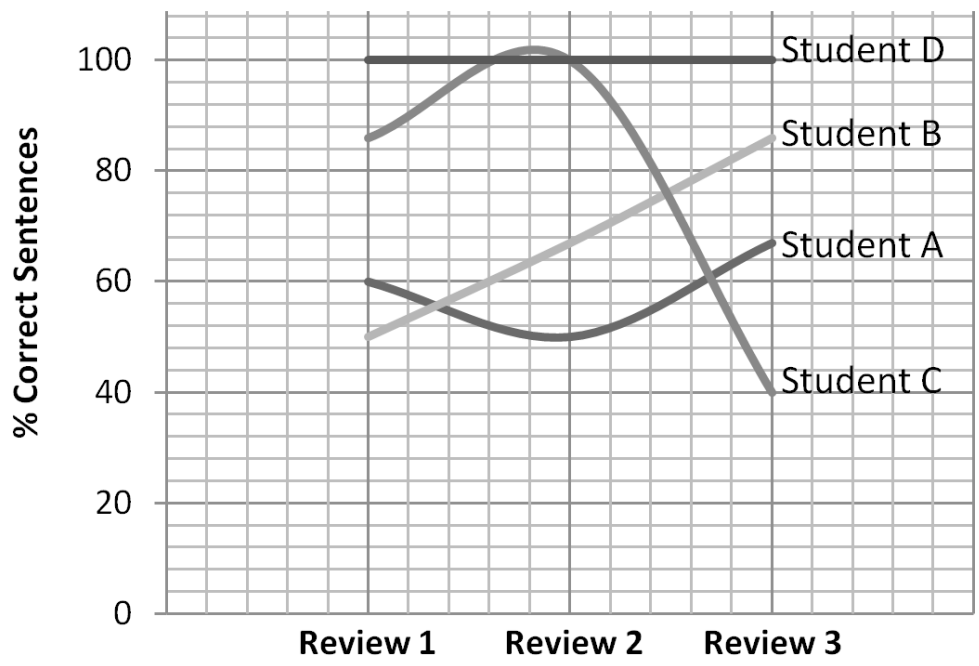

Figure 1: Students' performance on Reviews 1-3.

Student A's performance decreased on Review 2, but increased on Review 3. Student B presented a steady rise in performance. Student D remained stable throughout the process. In contrast, Student C improved on Review 2, but dropped dramatically on Review 3.

Other figures are presented in Appendices III and IV.

\section{Discussion}

The use of translation in Foreign Language Teaching has always been essential, although not generally recognized as such. The benefits of using translation to teach a foreign language certainly overcome the shortcomings. 
The data analysis showed that, after some time and a few corrections, my students were able to use correctly and more confidently the structures which they had been taught. Through their assignment results, I knew exactly what I should work on in order to help them advance. Corrections were made both through written and oral activities in the classroom. The learners performed well on translation exercises, knowing how to arrange subjects, verbs, objects, and adjectives correctly. Although the sentences in "Written Practice" did not have a common context, they were coherent and useful for conversation. Translating decontextualized, though realistic, sentences appears to be advantageous for a number of reasons. According to Petrocchi (2006, p. 3), "as a first approach, it is useful to translate short sentences in order to be able to build a longer paragraph and deepen the structure of the single phrase later on". Welker $(2003$, p. 7) also states that translating isolated sentences without a specific context is beneficial for beginners as they become aware of the particularities of translation, helping to prepare them for upcoming levels.

Most of the errors in the inventory (see Appendix II) stemmed from mother tongue influence, in this case, Portuguese. Naturally, there will always be first language interference to a certain extent, but this type of interference can be reduced as the student advances in learning. Heltai (1989, p. 289), referring to Krashen and Terrell (1983), asserts that "most interference errors are not interference errors at all, but developmental errors that will disappear as learners learn more of the language". Meanwhile, Stoddart (2000, p. 12) points out that "many of the linguistic errors produced by students are put down to L1 transfer" but he prefers to call this phenomenon "L1-L2 mistranslation". Finally, the inventory revealed that the students' performance on translation exercises was satisfactory, since the majority of the learners improved gradually (out of the four learners, only one failed the course). In other words, the translation exercises played an important role in the students' development. 


\section{Conclusion}

This study investigated the extent to which translation, through written exercises, is useful for fostering language learning at elementary levels. If not overused, translation turns out to be a powerful tool which bridges the gap between the mother tongue and a foreign language and thus promotes conscious learning. It has been argued that adult learners benefit more from translation because it is considered to be a cognitively demanding task.

The analysis drew only on data collected over three months of classes. This rather short period of time is a limitation of this study, and an in-depth analysis over a longer period should be carried out for obtaining more reliable findings. Moreover, oral translation should be given more emphasis when discussing the effectiveness of translation.

Nevertheless, the results showed that the performance of the majority of learners was a satisfactory one for basic level. Considering that errors and mother tongue interference tend to disappear over the learning process and that learners need to associate L1 with L2 in order to communicate, it is reasonable to state that translation does promote successful learning in Foreign Language Teaching.

A detailed study of the complex mental processes involved in forming associations between the mother tongue and a foreign language for translation purposes, as well as investigations of other teaching approaches or learning strategies would be relevant to the field and worthwhile contributions. 


\section{Notes}

1. Due to word limit, some sections of this article have been removed. They were of interest in the full version of this study. Please, contact the author by email to obtain this supplementary material.

2. "A step forward to using translation to teach a foreign/second language". The article presents a progress report on research on the use of translation as a main methodology to teach Japanese as a foreign language.

3. A test taken after every block of six lessons.

\section{Bibliography}

ATKINSON, D. The mother tongue in the classroom: a neglected resource? ELT Journal. Oxford: OUP, v. 41, n. 4, p. 241-247, 1987. . Teaching monolingual classes. London: Longman, 1993.

CATFORD, J. C. A linguistic theory of translation. Oxford: Oxford University Press, 1965.

COSTA, W. C. Tradução e ensino de línguas. In: BOHN H. I.; VANDRESEN, P. Tópicos em linguística aplicada: o ensino de línguas estrangeiras. Florianópolis: Ed. UFSC, 1988. p. 282-291.

DELLER, S.; RINVOLUCRI, M. Using the mother tongue - making the most of the learner's language. 1. ed. London: Delta Publishing, 2002. $96 \mathrm{p}$. 
DUFF, A. Translation. Oxford: Oxford University Press, 1989.

GABRIELATOS, C. Translation impossibilities: problems and opportunities for TEFL. TESOL Greece Newsletter, Athens, n. 60, p. 21-24, 1998. Available at: <http://www.gabrielatos.com/TranslationTEFL.pdf > . Accessed on: Mar. 7 2009.

HELTAI. P. Teaching vocabulary by oral translation. ELT Journal. Oxford: OUP, v. 43, n. 4, p. 289-293, 1989.

KRASHEN, S. D.; TERRELL, T. D. The Natural Approach. Language Aquisition in the Classroom. Oxford: Pergamon. 1983.

KREMER, L. M. S.; KOPPE, C. Translation in the EFL classroom: how and what to work. In: ENCONTRO DE PROFESSORES DE LÍNGUAS ESTRANGEIRAS DO PARANÁ, 15. 2007, Curitiba. Anais... Curitiba: [s.n], 2007. p. 440-448. Available at: < http://www.apliepar.com.br/site/anais_eple2007/artigos/41_CarmenKoppe_Kremer.pdf >. Acessed on: Jul. 92009.

LEWIS, M. Implementing the lexical approach - putting theory into practice. 1. ed. Boston: Thomson-Heinle, 2002. 223 p.

MACHIDA, S. A step forward to using translation to teach a foreign/ second language. Electronic Journal of Foreign Language Teaching, Singapore, v. 5, p. 140-155, 2008. Supplement. Available at: < http://e-flt.nus.edu.sg/v5sp12008/ machida.pdf >. Accessed on: Sep. 72009.

MALLIKAMAS, P. Translation as a language teaching technique. Thai TESOL Bulletin. Bangkok, v. 10, n. 1, p. 25-35, 1997.

PEGENAUTE, L. La traducción como herramienta didáctica. Contextos, Madrid, v. 14, n. 27/28, p. 107-126, 1996.

PETROCCHI, V. Translation as an aid in teaching English as a second language. Translation Journal, v. 10, n. 4, 2006. Available at: < http://accurapid.com/ Journal/38teaching.htm >. Accessed on: Sep. 72009. 
PHILIPPS, C. C. E. O uso discriminado e indiscriminado da tradução como estratégia de ensino de língua inglesa. 66 f. 2003. Dissertação (Mestrado em Educação) - Universidade do Vale do Itajaí, Itajaí, 2003. Available at: < http://www6.univali. br/tede/tde_busca/arquivo.php?codArquivo=38> . Accessed on: Sep. 72009.

POPOVIC, R. The place of translation in language teaching. Bridges, the Journal of the Thrace-Macedonia Teachers' Association. Thessaloniki, n. 5, p. 3-8, Jan. 2001. Available at: <http://www.sueleatherassociates.com/pdfs/Article translationinlanguageteaching.pdf $>$. Accessed on: Aug. 62009.

RIDD, M. D. Tradução, consciência crítica da linguagem e relações de poder no ensino de línguas estrangeiras. In: ENCONTRO NACIONAL DE INTERAÇÃO EM LINGUAGEM VERBAL E NÃO VERBAL, 7., 2004, Brasília. Atas... Brasília: Universidade de Brasília, 2004. v. 1, p. 1-8.

ROMANELLI, S. Traduzir ou não traduzir em sala de aula? Eis a questão. Inventário, Salvador, v. 5, 2006. Available at: <www.inventario.ufba.br/05/pdf/ sromanelli.pdf $>$. Accessed on: Sep. 72009.

SHIYAB, S.; ABDULLATEEF, M. Translation and foreign language teaching. Journal of King Saud University Language \& Translation. Riyadh: Saudi Arabia, v. 13, n. 1, 2001. Available at: <http://digital.library.ksu.edu.sa/ V13M163R428.pdf >. Accessed on: Oct. 102009.

SOARES, E. Tradução e ensino de línguas estrangeiras. Scientia Traductionis, Florianópolis, v. 3, 2006. Available at: <www.scientiatraductionis.ufsc.br/ensino.pdf >. Accessed on: Sep. 72009.

STODDART, J. Teaching through translation. British Council Journal. Lisbon, n. 11, 2000. Available at: <http://www.britishcouncil.org/portugal-inenglish-2000apr-teaching-through-translation.pdf > . Accessed on: Sep. 72009.

THOMPSON, G. Using bilingual dictionaries. ELT Journal. Oxford: OUP, v. 41, n. 4, p. 282-286, 1987.

WELKER, H. A. Traduzir frases isoladas na aula de língua estrangeira - por que não? Horizontes de Linguística Aplicada, Brasília, v. 3, p. 149-162, 2004. Avai- 
lable at: <http://www.let.unb.br/hawelker/tradfras.pdf $>$. Accessed on: Sep. 7 2009.

WIDDOWSON, H. G. The deep structure of discourse and the use of translation. In: (Ed.). Explorations in applied linguistics. Oxford: Oxford University Press, 1979. p. 101-111. 


\section{APPENDIX I}

\section{REVIEW 1}

\section{St: Student}

EA: Expected Answer

\section{WRITTEN PRACTICE}

1. Eu como pão, presunto e queijo no café da manhã.

EA: I eat bread, ham and cheese for breakfast.

St1. Ok

St2. Ok

St3. Ok

St4. Ok

2. Você gosta de tomar um copo de suco todos os dias?

EA: Do you like to drink a glass of juice every day?

St1. Do you like of drink a glass of juice every day?

St2. Do you like a drink of glass of the juice every day?

St3. Do you like to drink of glass every day?

St4. Ok

3. Eu gosto da minha casa nova e do meu carro velho.

EA: I like my new house and my old car.

St1. I like to my new house and to my old car.

St2. I like my new house and of my old car.

St3. Ok

St4. Ok

4. Você gosta de falar com seu marido de manhã?

EA: Do you like to speak with your husband in the morning? 
St1. Ok

St2. Do you like St3. Ok St4. Ok speak with your husband in the morning?

5. Você trabalha sozinho ou com seus amigos na escola?

EA: Do you work alone or with your friends at school?

St1. Ok

St2. Ok

St3. Ok

St4. Ok

6. Eu gosto de beber somente uma xícara de chá de manhã. EA: I like to drink only a cup of tea in the morning.

St1. Ok

St2. I like St3. Ok only St4. Ok cup of tea in the morning.

7. Eu estudo inglês com meus amigos na escola. EA: I study English with my friends at school.

St1. Ok St2. Ok St3. Ok St4. Ok

8. Eu gosto de jogar futebol com meus filhos à noite. EA: I like to play soccer with my children at night.

St1. I drink to play soccer with my children at night. St2. Ok St3. Ok St4. Ok 


\section{APPENDIX II INVENTORY OF ERRORS}

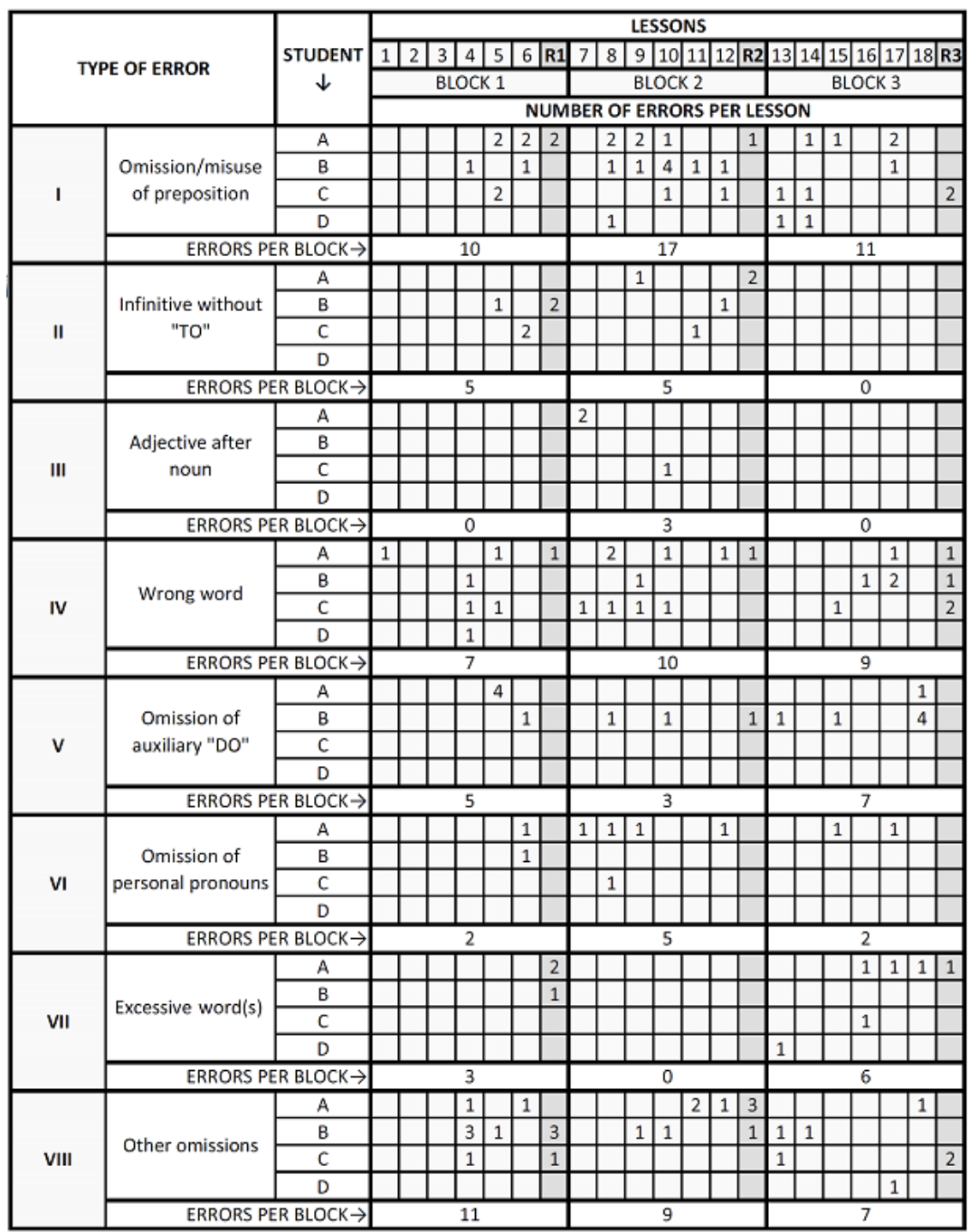




\section{APPENDIX III}

\section{COMPARATIVE GRAPHS}

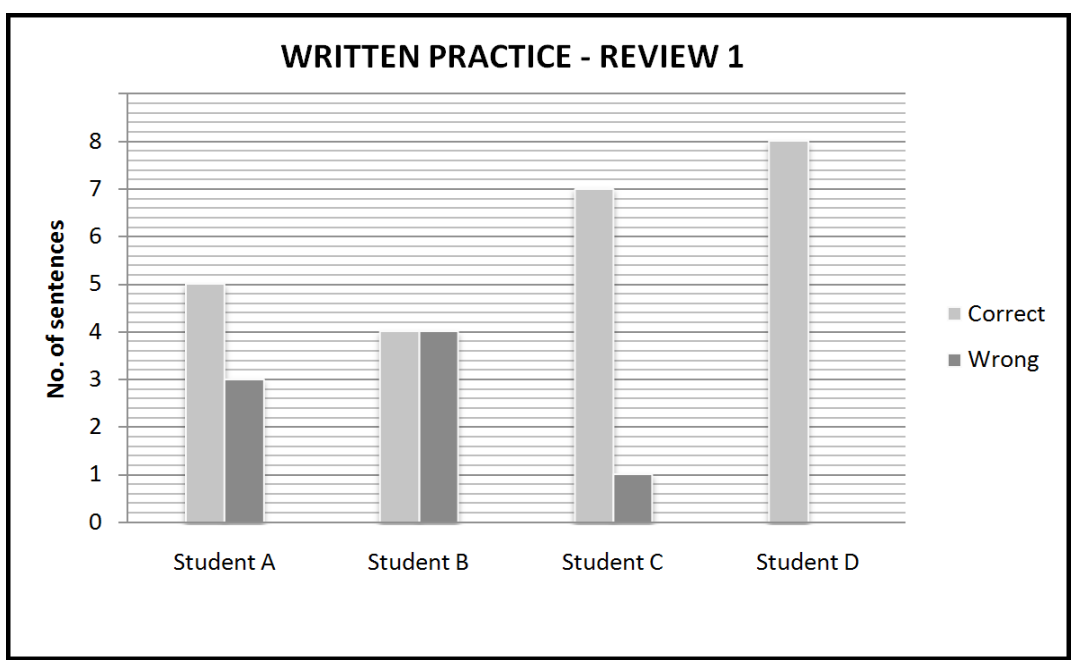

Figure 2: Students' performance on Review 1

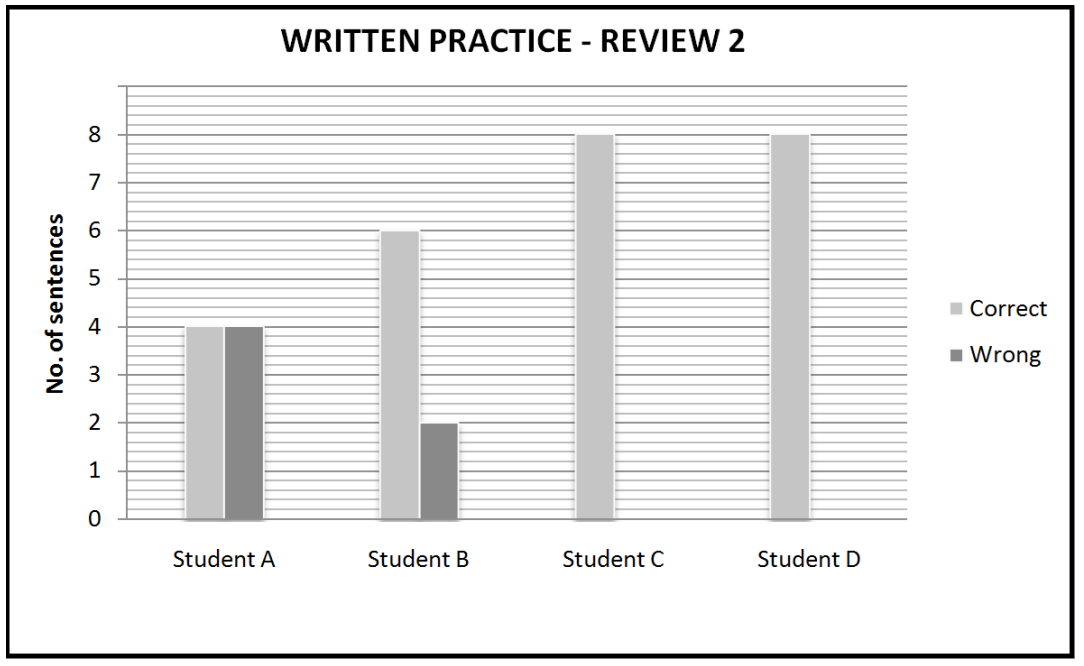

Figure 3: Students' performance on Review 2 


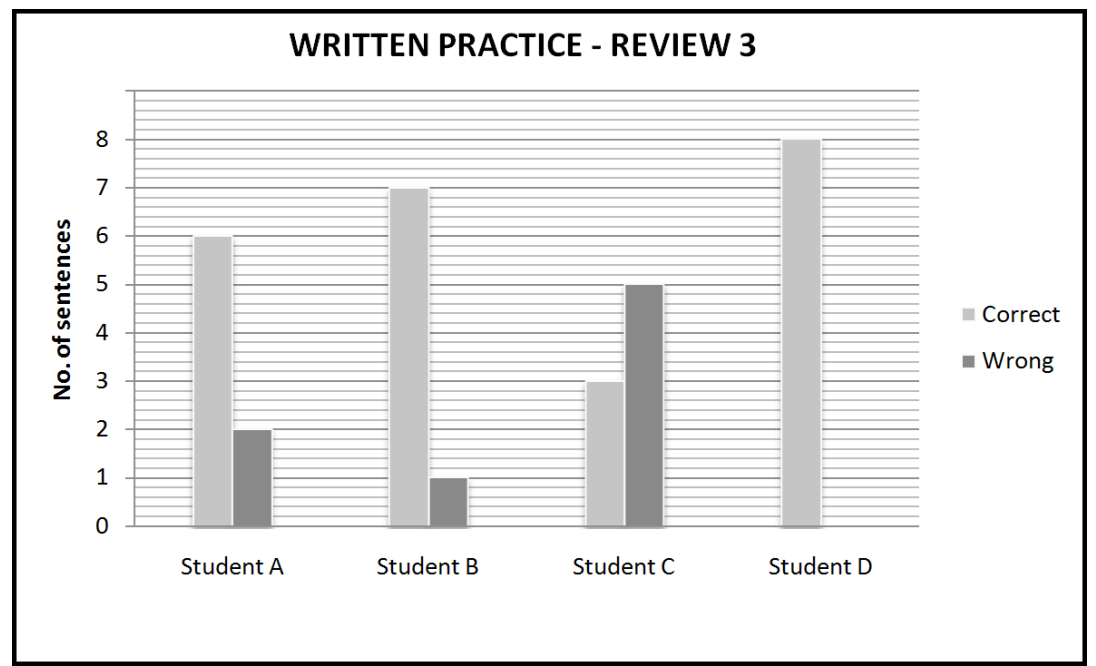

Figure 4: Students' performance on Review 3 


\section{APPENDIX IV}

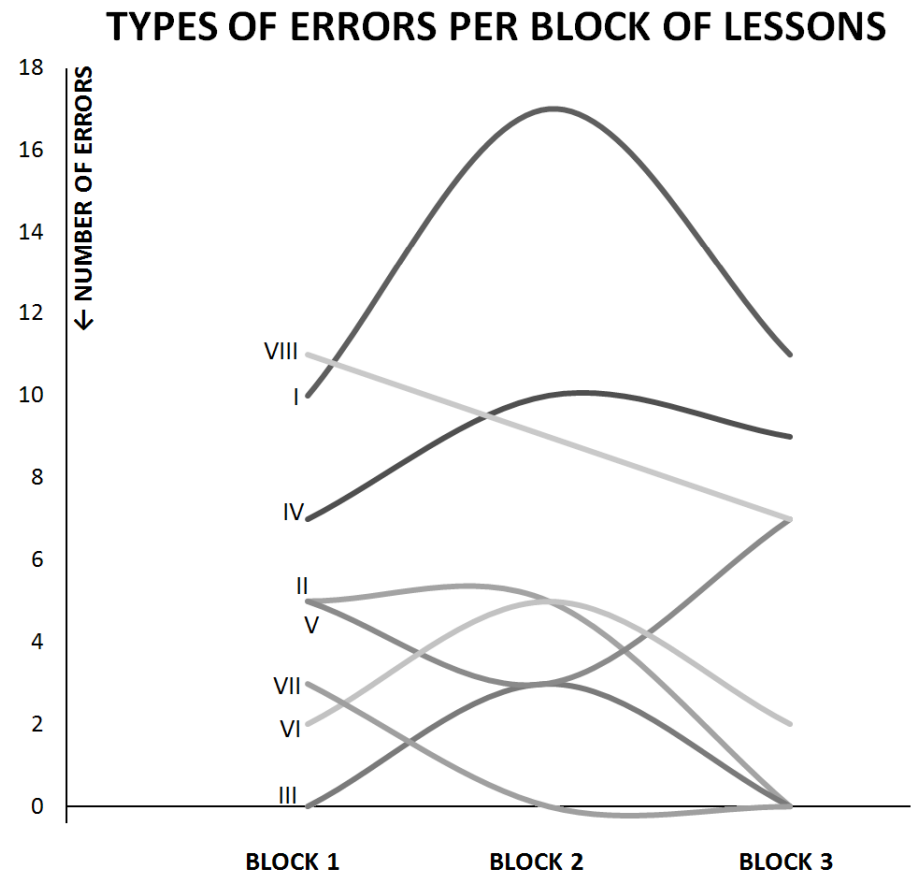

Figure 5: Students' performance according to error type per block of lessons.

For further information, see Appendix II. 